\title{
A study on Nymphs and Exuviae of Order Odonata in Nalsarovar Bird Sanctuary (Ramsar Site), Gujarat
}

\author{
Kalavanti Mokaria $^{1^{*}}$ and Bharat Jethva ${ }^{2}$ \\ ${ }^{1,2}$ Mahatma Jyoti Rao Phoole University, Jaipur, Rajasthan, India \\ *Corresponding Author: kala303@gmailcom
}

Available online at: www.isroset.org

Received: 05/Dec/2018, Accepted: 21/Dec/2018, Online: 31/Dec/2018

\begin{abstract}
A study was carried out in Nalsarovar Bird Sanctuary to assess nymphs and exuviae of dragonflies and damselflies in Nalsarovar Bird Sanctuary (Ramsar Site), Gujarat. A transect survey was carried out covering all seasons. Nymph and exuviae were recorded using Visual Encounter Survey. During survey Odonate nymph and exuviae belonging to five families including Aeshnidae, Libellulidae, Gomphidae, Coenagrionidae, and Lestidae were recorded. Seasonal variations in relative abundance of each family of odonate were analyzed. The relative abundance of Odonates nymph that belonged to family Libellulidae and Coenagrionidae was recorded highest during monsoon, postmonsoon, winter and summer seasons whereas Gomphidae and Coenagrionidae were highest during the pre-monsoon season. However, the relative abundance of Aeshnidae family nymphs was moderate during the postmonsoon season. Similarly, the relative abundance of Odonates exuviae that belonged to family Libellulidae and Coenagrionidae was highest during all seasons. However, the relative abundance of Aeshnidae family exuviae were moderate during the postmonsoon season whereas Lestidae family exuviae was less during the summer and winter season.
\end{abstract}

Keywords- Damselfly, Dragonfly, Exuviae, Nalsarovar Bird Sanctuary, Nymph, Odonata

\section{INTRODUCTION}

Dragonfly (Suborder-Anisoptera) and Damselflies (Suborder-Zygoptera) both belong to Order Odonata. Odonata is one of the most ancient groups of insects that first appeared during the Carboniferous era, about 250 million years ago [1]. Odonates have pass through three stages during entire life i.e. eggs, nymph (larvae) and adult. The Odonates are amphibiotic insects. They spend a major part of their life cycle in a freshwater ecosystem. Odonate nymphs are carnivores and voracious feeder whereas adults are a predator of other insect species [2]. Odonates have an aquatic immature stage (nymphs/larvae) and terrestrial (adult) stages. Exuviae are the dried skin of the last larval/nymphal instar. At the end of the larval life, the larvae find a support such as a rock or plant stems, where it can tear up its skin and winged adult emerges from last larval stage [3].

Globally 5,952 species of Odonates belonging to 652 genera have been reported [4]. India harbors 474 species and 50 subspecies belonging to 142 genera in 18 families [5]. In Nalsarovar Sanctuary, 37 species of Odonata are recorded including both dragonflies and damselflies [6]. The entire study was carried out in Nalsarovar wetland. Nalsarovar Sanctuary is one of the important wetlands of India and Gujarat. It is internationally recognized as a Ramsar Site of Gujarat. It is also designated as a Sanctuary i.e. protected area and an Important Bird and Biodiversity Area (IBA) [7].
Nalsarovar wetland is a seasonal wetland. It is moreover elliptical in shape. The basin of Nalsarovar is of elongate undulating saucer type and its overall shape is very gentle, running from east to northwest and northwest to south. Generally, the depth of water does not exceed 3 meters [8],[9]. There are more than 300 elevated plateaus in the basin locally called 'Bet' or 'Thalias' meaning islets as they remain above the water surface. The natural and seasonal spread of wetland of Nalsarovar is of irregular shape. It is shallow and in most parts muddy. This depressed portion had come into existence by a tectonic uplift of an estuary as also by increased sedimentation and aeolian infill [10]. Studies on various aspect of Nalsarovar are done in past including birds and biodiversity study [6],[11],[12].

Odonates larval (nymphs) and adult stage play a significant role as a predator in the wetland ecosystem as a biocontrol agent. However, Odonates also act as a biocontrol agent of many disease-causing species including mosquitoes i.e. a vector of malaria and dengue as well as helminths i.e. parasites of birds especially of poultry and wild ducks which thereby aid transmission of these diseases [1],[13],[14],[15],[16],[17],

[18],[19],[20].

With more and more human disturbance Odonate value as indicators of quality of the biotope is now being increasingly 
recognized. Odonates have been deemed as "flagship" group of indicators species [21]. Species assemblage of dragonflies and its emergence from nymphs to adult stage, changes with seasonal changes [22]. However, those counts of exuviae can give a clearer picture of real dragonfly abundance and their numbers emerging from water bodies can be used for monitoring [3].

Studies on aquatic insects are limited within Gujarat state. Some studies focused on aquatic and semi-aquatic insects in Gujarat State [5],[23],[24],[25],[26],[27],[28],[29]. The structure and composition of these aquatic communities like Odonates nymphs and emergence from nymphs i.e. exuviae indicate the reproductive success of wetland and also indirectly act as an indicator of the quality of water and reflect overall ecological integrity [30],[31]. However, Odonata being such an important semiaquatic insect there is a gap of studies on immature stages of dragonflies and damselflies from Gujarat state. However, no studies focusing on the ecology of immature stages of insect from Gujarat state is carried out. Considering the important role played by Odonata in terms of monitoring the wetland health, this study was undertaken to make a baseline for future monitoring of Nalsarovar wetland as well as for similar wetland within Gujarat state.

\section{STUDY AREA}

The study was carried out at Nalsarovar Bird Sanctuary. Nalsarovar is located between $22^{\circ} 78^{\prime} \mathrm{N}$ and $22^{\circ} 96^{\prime} \mathrm{N}$ latitude and $71^{\circ} 92^{\prime} \mathrm{E}$ and $72^{\circ} 64^{\prime} \mathrm{E}$ longitudes. The lake area is spread over two districts viz., Ahmedabad and Surendranagar. It has an area of 147 sq. km. [32]. Biogeographically, the area falls in Gujarat-Rajwara Biotic Province (4B) of the Semi-Arid biogeographical zone [33]. There are about 12 villages located on the periphery of this wetland. They include Kayla, Vekaria, Meni, Darji, Digvijaygadh, Shiyal, Paraii, Mulbavla, Ranagadh, Bhagvnpur, Nani Kathechi, and Shahpur.

The natural and seasonal spread of wetland of Nalsarovar has an irregular configuration, though the basin is elliptical in shape. It is shallow with a maximum depth of $3 \mathrm{~m}$ and in most parts muddy. Nalsarovar is unique both in structural and physical characteristics compared to other wetlands of Gujarat. Geologically it is the remnant relict of an oceanic creek locally called as Nal. This depressed portion had come into existence by a tectonic uplift of an estuary and also by increased sedimentation and aeolian infill [9].

Being a natural lake, the area under the submergence varies seasonally and annually depending upon the rainfall and the climate of the area is arid to semi-arid in nature. The temperature attains a maximum of $45^{\circ} \mathrm{C}$ during the month of May and falls below $7^{\circ} \mathrm{C}$ in January. The rise in the temperature after peak winter accelerates the rate of evaporation of water in the lake and thereby results in rapid drying [6],[34]. The rainfall is erratic. During the good rainfall years, the total area under submergence swells to around $350 \mathrm{sq} . \mathrm{km}$ whereas submergence area is often $60 \mathrm{sq}$ $\mathrm{km}$ during winter of normal rain year. The entire land of Nalsarovar and its environs is salt-affected with saline/alkaline salts concentrated in the upper layer of clayey, medium black soil [8].

Apart from rainfall and the temperature, wind also plays an important role in the area. During summer the wind velocity can be as high as $60 \mathrm{~km} / \mathrm{hr}$ which also accelerates the rate of evaporation of water from the lake [6].

The change in water quality between fresh and brackish keeps the bio-cycles of organisms. Nalsarovar provides adequate depression over a large area for the existence of submerged aquatic vegetation. Moreover, in and around its shallow water near the shores and islets, it supports emergent hydrophytic vegetation. Both the submerged and emergent vegetation, as well as algae, constitute primary producers of this aquatic ecosystem. They support large epiphytic macroinvertebrates and also provide cover to a variety of organisms [35],[6],[33]. The major habitats of Nalsarovar wetland include Open Water Habitat, Emergent Hydrophytic Cover, Muddy Habitat, Islets ('bet'), Shore-land, Agriculture fields surrounding the Lake, wasteland surrounding the Lake and Inlets and Outlets of Lake [33].

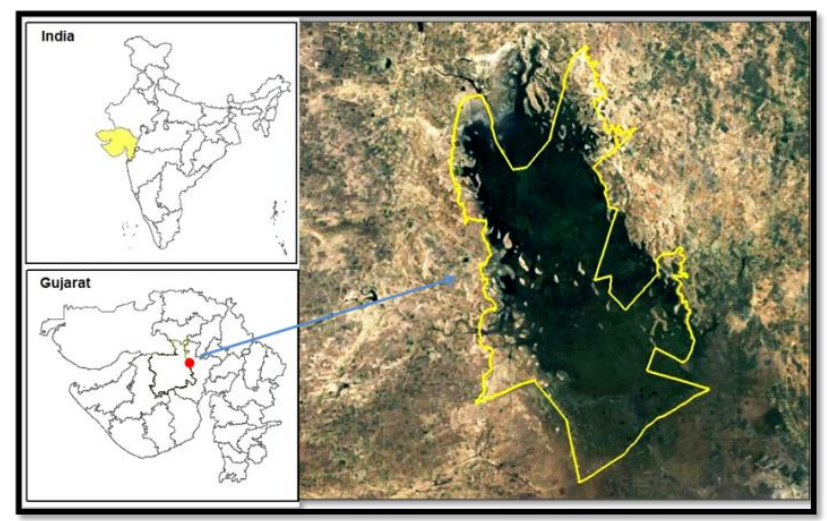

Map 1: Location map of Nalsarovar wetland

\section{MATERIALS AND METHODS}

A study of odonates was carried out from February 2015 to February 2017 at Nalsarovar Bird Sanctuary. Fourteen sites were fixed using GPS for the odonate survey within the study area (from T1 to T14). The survey was carried out covering different seasons and covering all major habitats. These sites were regularly and repeatedly surveyed for recording nymphs and exuviae. Fixed belt transects of $500 \mathrm{~m}$ length and width of $5 \mathrm{~m}$ on both side of transect were followed for the study of odonates [36]. Odonate nymph survey was carried out using the Aquatic net. Total 10 haults were carried out along the length of transect for counting Odonate nymphs. A quadrate survey $(10 \mathrm{mX} 10 \mathrm{~m})$ with a minimum distance of $200 \mathrm{~m}$ along the length of transects was 
carried out for the exuviae survey. Visual Encounter Survey (VES) on a fixed point were carried out. Individuals (nymphs and exuviae) of different families of Odonates were recorded during the survey, photographed and then released back to the field. Species were mainly photographed using digital photos by Canon Powershot SX60 HS camera with 16.1 megapixels, ultrasonic, full HD $65 \mathrm{X}$ optical zoom. Species were identifications to the best possible level (i.e. family level) at Nalsarovar Bird Sanctuary. Identification was carried out with available standard taxonomic literature [37],[38],[39],[40]. The raw data recorded from all the sites were transferred in an electronic format in spreadsheet layout (Microsoft excels) and data was analyzed to calculate relative abundance.

\section{RESULTS AND DISCUSSION}

During the entire survey, seasonal variation in relative abundance of dragonfly nymph and exuviae was calculated based on data collected. During the entire survey, Odonate nymphs belonging to 5 different families namely Libellulidae, Aeshnidae, Gomphidae, Coenagrionidae and Lestidae were encountered. Out of total Odonate families encountered, three families belonged to Anisoptera i.e. Dragonflies (Libellulidae, Aeshnidae and Gomphidae) and two families belonged to Damselflies (Coenagrionidae and Lestidae). However, Odonate exuviae belonging to 4 different families were encountered namely Libellulidae, Aeshnidae, Coenagrionidae, and Lestidae. Odonates species composition varies across different land use types and across seasons. There is variation in species diversity and abundance according to different habitat as well [41]. During these studies, seasonal variation in relative abundance of odonate nymphs and exuviae was calculated.

Relative abundance of Nymphs: During pre-monsoon season, the relative abundance of nymphs of Odonates belonging to family Gomphidae (i.e. $72.02 \%$ ) was recorded highest followed by family Coenagrionidae (i.e. $15.20 \%$ ) and further followed by family Libellulidae (i.e. 12.80\%). During monsoon season, the relative abundance of nymphs of Odonates belonging to family Libellulidae (i.e. $52.58 \%$ ) was recorded highest followed by family Coenagrionidae $(47.45 \%)$. During the postmonsoon season, the relative abundance of nymphs of Odonates belonging to family Libellulidae $(37.42 \%)$ was recorded highest followed by Coenagrionidae $(32.89 \%)$ and Aeshnidae $(17.95 \%)$ which was further followed by Lestidae $(11.75 \%)$. During the winter season, the relative abundance of nymphs of Odonates belonging to family Coenagrionidae $(61.99 \%)$ was recorded highest followed by Libellulidae (33.61\%) which was further followed by Lestidae (4.39 \%). During the summer season, the relative abundance of nymphs of Odonates belonging to family Libellulidae $(56.78 \%)$ was recorded highest which was further followed by family Coenagrionidae $(41.10 \%)$ and Lestidae $(2.12 \%)$.

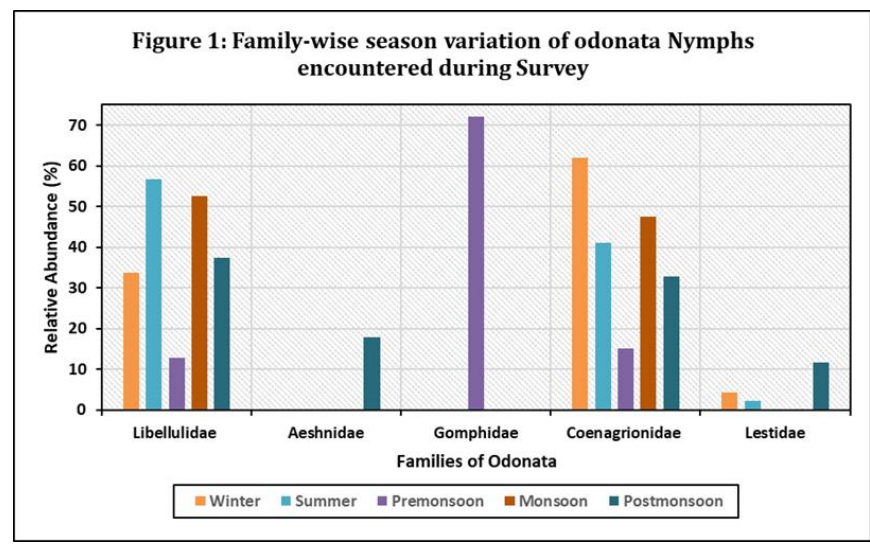

Relative abundance of Exuviae: During the premonsoon season survey, the relative abundance of exuviae of Odonates belonging to family Libellulidae (i.e $80.00 \%$ ) was recorded highest followed by family Coenagrionidae (i.e. $20.00 \%$ ). During monsoon season survey, the relative abundance of exuviae of Odonates belonging to family Libellulidae (i.e. $54.65 \%$ ) was recorded highest followed by Coenagrionidae (i.e. $45.36 \%$ ). During the postmonsoon season, the relative abundance of exuviae of Odonates belonging to family Libellulidae $(46.07 \%)$ was recorded highest followed by Coenagrionidae $(34.47 \%)$ which was further followed by Aeshnidae (19.47\%). During the winter season, the relative abundance of exuviae of Odonates belonging to family Libellulidae $(49.30 \%)$ was recorded highest followed by Coenagrionidae $(45.92 \%)$ which was further followed by Lestidae $(4.79 \%)$. During the summer season, the relative abundance of exuviae of Odonates belonging to family Libellulidae $(50.83 \%)$ was recorded highest which was followed by Coenagrionidae $(41.81 \%$ ) which was further followed by Lestidae $(7.38 \%)$. This variation may due to seasonal and environmental changes, as the emergence of odonates are known to have some correlation with changes in abiotic factors like water temperature [47].

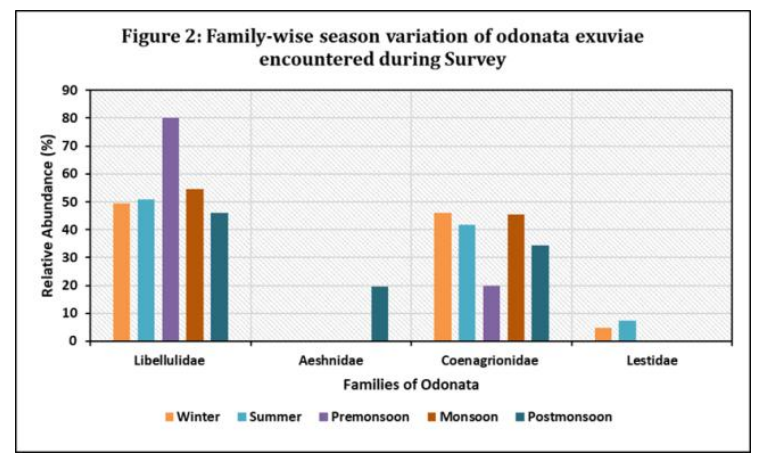

Odonates are known to have correlation with abiotic factors. Due to their significant correlation with environment, it is very important to study Odonates from all possible biogeographic zones. However, sensitivity of Orders 
Odonata to temperature ranges and with Dissolved Oxygen is very well studied. Seasonal variation observed during studies may be mainly due to abiotic factors, as these abiotic factors directly influence on odonate biodiversity and richness of species. Due to such correlation Odonates are considered as potential bioindicator of water quality and a means of evaluating the efficiency of an aquatic system [3],[42],[43],[44],[45],[46].

\section{CONCLUSIONS}

The freshwater aquatic ecosystem is more and more subjected to threats mainly being subjected to increased levels of human disturbance worldwide [48]. There is a need to conserve these wetlands and its associated species. Odonates nymphs and their emergence are linked to its associated fauna, flora, water quality and environmental condition. Changes in basic habitat and environmental condition may cause changes in the assemblage of Odonates population in temporary water bodies as well as it may also cause local extinctions of resident species in the future. Variation in Odonate nymphs may indicate changes in water quality. Similarly, seasonal variation in relative abundance of exuvia indicates variation in the emergence pattern of Odonates from Nalsarovar wetland. Such correlation can be established with further studies on Odonates in detail. With increases in more and more wetland monitoring studies and restoration of degraded ecosystems as a part of conservation and sustainable management of aquatic ecosystems may reduce the threats on dragonfly and damselfly species.

\section{ACKNOWLEDGMENTS}

Authors are thankful to Gujarat Forest Department for support during entire research and also thankful to Forest managers for providing necessary facilities in field. The author is also thankful to Dr. Preeti Srivastava, Ex-faculty at Mahatma Jyoti Rao Phoole University (MJRPU) and faculties of the university for support and research related guidance.

\section{REFERENCES}

[1]. Subramanian, K. A. (2005). Dragonflies and damselflies of peninsular India-A Field Guide. Project landscape Indian Academy of Sciences Banglore, India, pp 1-118

[2]. Andrew, R.J., K.A. Subramanian \& A.D. Tiple (2009). A Handbook on Common Odonates of Central India. South Asian Council of Odonatology, pp 1-65

[3]. Paul, S. and Kakkassery, F. K. (2013). Taxonomic and Diversity Studies on Odonate Nymphs by Using Their Exuviae, Journal of Entomology and Zoology Studies, 1(4) pp 47-53

[4]. Schorr, M. and Paulson, D. (2013) World Odonata List Slater Museum of Natural History, Electronic Database access at November 2013

[5]. Subramanian, K. A. (2014). A checklist of Odonata (Insecta) of India. Zoological Survey of India, Kolkata, pp 1-31
[6]. Mokaria. K., and Jethva B., (2018). Diversity, Local Distribution and Occurrence of Dragonflies and Damselflies (Odonata: Insecta) In Nal Sarovar Bird Sanctuary (Ramsar Site), Gujarat International Journal of Scientific and Research Publications, ISSN 2250-3153, $8(1)$, pp $61-73$

[7]. GEER, (1998) Environmental Impact Assessment of Sardar Sarovar Project on Nal Sarovar Bird Sanctuary. Final Technical Report submitted to Narmada Planning Group, Sardar Sarovar Narmada Nigam Limited, Gandhinagar. Gujarat Ecological Education and Research (GEER) Foundation, Gandhinagar, pp 1138

[8]. Acharya, H.G. (1965). A note on the Nal, Prakriti - Journal of Gujarat Natural History Society, Vol. 12. (3 \& 4). pp 1-16.

[9]. Johri, A., Ramani, K. R., Suthar. D. C. and Patel, G. A. (1990). Management plan for Nal Sarovar Bird Sanctuary, 1990-2000, Gujarat State Forest Department. Gandhinagar

[10]. Walsten, J. A., Hussain, S. A., and Varshney. C. K. (1989). Nal Sarovar Lake and the Surendranagar reservoirs in A directory of Asian Wetlands (Ed. D.A. Scott), IUCN, Gland \& Cambridge, pp 429-430.

[11]. Stanley, O.D. (2004). Wetland ecosystems and coastal habitat diversity in Gujarat, India. Journal of Coastal Development.7 (2), pp-49-64

[12]. Bhavsar, R. N., Singh N. P., and Prakash I. (2014). Identification of Wetland Vegetation by Supervised Classification of $\mathrm{Nal}$ Sarovar Area using LISS-III Data International Journal for Scientific Research \& Development ISSN (online): 2321-0613, 2(2) pp 162-164

[13]. Chandra, G., Chatterjee, S. N., and Ghosh A. (2006). Role of dragonfly (Brachytron pratense) nymph as a biocontrol agent of larval mosquitoes, Bul. Penel. Kesehatan, 34, (4), pp 147-151

[14]. Brown, K. (1991). Conservation of insects and their habitats: insects as indicators. In: Collins M, Thomas JA, Editors. The conservation of insects and their habitats, Academic Press. pp 350404.

[15]. Clark, T. E., and Samways, M. J. (1996). Dragonflies (Odonata) as indicators of biotope quality in the Kruger National Park, South Africa. Journal of Applied Ecology, 33(1), pp 1001-1012.

[16]. Samways, M. J., McGeoch, M. A., and New, T. R. (2010). Insect Conservation: A handbook of approaches and methods. Oxford University Press.

[17]. Tiple, A. D., (2012). Dragonflies and Damselflies (Odonata: Insecta) of the Achanakmar Amarkantak Biosphere Reserve, in Chhattisgarh and Madhya Pradesh, with their status in Central India. International Journal of. Biotechnology and Biological Science, 2(1) pp 97-102.

[18]. Thomas, M., Daniel, M. A., and Gladsutone, M. (1988). Studies on the food preference in three species of Dragonfly naiads with particular emphasis on mosquito larvae predation. Bicovas, Vol 1, pp 34-41.

[19]. Santamarina, H., and Mijares, A. (1986) Odonata as bioregulators of the larval phase of mosquitoes. Revi. cubana de. MedinaTropical, 38111, 89-97.

[20]. Sebustian, A., Myint, S., Myat, T., and Corbet, P. S. (1990). Suppression of Aedes aegypti (Diptera: Culicidae) using augumentative release of larvae Odonata: Libellulidae with community participation in Yangon, Myanmar. Bull. Ento Res., 80, pp 223-232.

[21]. Oertli, B., J., D.A., Castella, E., J., R., Cambin, D. \& Lachavanne, J. B. (2002). Does size matter? The relationship between pond area and biodiversity. Biological Conservation, 104, pp 59-70.

[22]. Muthukumaravel K., R. BoseRaja, A. Amsath, S. Prabakaran, and Y. Chezhian (2015). Seasonal Variation Of Dragonflies Diversity In Muthupet Mangrove Forest, Tamil Nadu, India; International Journal of Pure and Applied Zoology; ISSN (Online): 2320-9585, 3(2), pp: 188-192 
[23]. Prasad, M., and Thakur, R. K. (1984). On a collection of Odonata from Gujarat State, India. Fraseria, 6, pp 24 - 25.

[24]. Pilo, B., Pathak, B., Kumar, B. A., Murukesan, V. K., Vinod, K. R., Kumari, S. (1996). Biological Diversity of Gujarat, Gujarat Ecology Commission, GERI Campus, Race Course Road, Vadodara

[25]. Prasad, M. (2004). Insecta: Odonata of Gujarat. Fauna of Gujarat, Zool. Surv. India, Kolkata, State Fauna Series, 8(2), pp 19-40

[26]. GEER (2012). Collection of Baseline Data Pertaining to Biodiversity and Socio-Economics in the Dholera Special Investment Region, Gujarat Report no DSIR/64/2012 Gujarat Ecological Education and Research (GEER) Foundation, Gandhinagar. Pp 1-374

[27]. Mokaria, K., (2015). Odonates of Freshwater Wetlands Around Thol Bird Sanctuary and Blackbuck National Park, Gujarat Jalaplavit (ISSN 2321-1881), Vol.6, No.3 (Research Special) pp $22-37$

[28]. Rathod, D. M., Dholu S. G., Parasharya B. M. and Mistry V (2015). Odonate Diversity of a Wetland of National ImportancePariej Jalaplavit (Research Special), ISSN 2321-1881, 6(3), pp 6 16

[29]. Mokaria, K., Tatu, K. and Kamboj, R. D., (2018). Current status of Entomofaunal Diversity of Khijadiya Wetland, Jamnagar Gujarat, India Jalaplavit (ISSN 2321-1881), 7(3), pp 16 -31

[30]. Patil, J. V. (2011). Study of selected Faunal Biodiversity of Toranmal area Toranmal Reserve Forest Ph.D. thesis, The Maharaja Sayajirao University of Baroda, Department of Zoology, pp. $1-267$

[31]. Farkas A., Tibor J, Ole M., Arnold M., Ibolya L., and György D. (2013). Sex ratio in Gomphidae (Odonata) at emergence: is there a relationship with water temperature, International Journal of Odonatology, 16(4), pp 279287

[32]. SAC-ISRO (2010). National Wetland Atlas: Gujarat, SAC/RESA/AFEG/NWIA/ATLAS/21/2010 Space Applications Centre (ISRO), Ahmedabad, India. pp 1-198.

[33]. Rodgers, W.A and Panwar, H.S. (1988). Planning a Wildlife Protected Area Network (PAN) in India. State Summaries. Vol. II. Wildlife Institute of India (WII), Dehra Dun.

[34]. Kamboj, R. D., and Tatu, K. (2016). Nal Sarovar Lake - an incredible rendezvous point of wetland denizens in Gujarat, Gujarat Ecological Education and Research (GEER) Foundation, Gandhinagar: pp 1-49

[35]. Tatu, K. (1995). Ecological study of Nalsarovar (Gujarat) with an emphasis on its floristic \& avifauna profile using satellite remote sensing technique. Ph. D. Thesis, Gujarat University, Ahmedabad

[36]. Sutherland, W. J., (1996). Ecological census techniques. A handbook Cambridge: Cambridge University Press, pp 1-336

[37]. Fraser, F. C. (1933) Odonata Vol. I. The Fauna of British India, Ceylon and Burma. Today \& Tomorrow's printers \& Publishers, New Delhi pp 1-423

[38]. Fraser, F. C. (1934). Odonata Vol. II. The Fauna of British India, Ceylon and Burma. Today \& Tomorrow's printers \& Publishers, New Delhi. pp 1-398.

[39]. Fraser, F. C. (1936) Odonata Vol. III. The Fauna of British India, Ceylon and Burma. Today \& Tomorrow's printers \& Publishers, New Delhi. pp 1-461.

[40]. Subramanian K. A. (2012). A Field guide to Aquatic insects of India, Zoological Survey of India, Kolkata, pp 1-68

[41]. Kulkarni A. S. and Subramanian K.A. (2013). Habitat and seasonal distribution of Odonata (Insecta) of Mula and Mutha river basins, Maharashtra, India., Journal of Threatened Taxa, Volume 5(7), pp 4084-4095

[42]. Catling, Paul M. (2005). A potential for the use of dragonfly (Odonata) diversity as a bioindicator of the efficiency of sewage lagoons. Canadian Field-Naturalist 119(2), pp 233-236.
[43]. Nebeker A. V. and Armond E. Lemke (1968) Preliminary Studies On the Tolerance of Aquatic Insects to Heated Waters National Water Quality Laboratory, Federal Water Pollution Control Administration, Duluth, Minnesota Journal of Kansas Entomological Society, 41(3), pp $413-418$

[44]. Smith, D.G., (1995). Keys to the Freshwater Macro Invertebrates of Massachusetts. Published by D.G. Smith, Amherst, MA, 413, pp 545-1956.

[45]. Payakka A and Prommi T., (2014). Aquatic Insects Biodiversity and Water Quality Parameters of Receiving Waterbody, Faculty of Liberal Arts and Science, Kasetsart University, Thailand, Current World Environment, Vol. 9(1), pp 53-58

[46]. Abowei, J.F.N., and Ukoroije, B.R. (2012). The identification, types, taxonomic orders, biodiversity, and importance of aquatic insects. British Journal of Pharmacology and Toxicology, 3(5), pp 218- 229.

[47]. Haslam, C. (2004). Chronological Patterns of Emergence of Dragonflies in Carver Pond, Bridgewater, MA. Undergraduate Review, 1, pp 62-72

[48]. Saunder D. L., Meeuwig J.J, and Vincent T. R., (2002). Freshwater protected areas: strategies for conservation. Conservation biology, 16(1), pp 30-41. 